Kostiantyn Kyrychenko, Head of the International Affairs Office, Sumy State University, Sumy, Ukraine

Yaryna Samusevych, Ph.D., Senior Lecturer, Accounting and Taxation Department, Sumy State University, Sumy, Ukraine

Liliia Liulova, Ph.D. student, Economics, Entrepreneurship and Business Administration Department,

Sumy State University, Sumy, Ukraine

Kseniya Bagmet, Ph.D., Doctoral student, International Economic Relations Department, Sumy State University, Sumy, Ukraine

\title{
INNOVATIONS IN COUNTRY'S SOCIAL DEVELOPMENT LEVEL ESTIMATION
}

Social development of a country is characterized by a large set of the population welfare parameters, which determines the need to select the most common indicators for its estimation. In the article approaches the interpretation of the essence and the determination of components of social development are investigates. The existing approach to social development estimation is analysed. Comparison of the peculiarities of grouping social indicators within these approaches is carried out. The article aims to find a universal methodology for the social development estimation in the context of the selected country. The research of the methodology of social development estimation was conducted by means of 1) a comparative analysis of the social development directions, as well as the composition of specific indicators in various methodologies of social development estimation; 2) normalization of indicators using minimaxing method to bring them into a comparable view; 3) testing of the internal consistency of indicators (Cronbach coefficient Alpha); 4) Simple Additive Weighting of indicators. The formed basic set of indicators for the social development estimation of the country includes 28 indicators, which can be divided into eight groups. Taking into consideration the nationally specific presentation of the statistical information, the composite index of social development for Ukraine was calculated on the basis of 19 specific indicators. The results of the estimation on an example of Ukraine reported a general permanent improvement of social development for the period 2010-2016, which also occurred in most of the components in the structure of the index except the indicators of Safety, Social Cohesion and Social Activity which in general for the period have declined, while Economic Security has been characterized by an unstable level.

Keywords: social development, estimation, Ukraine, methodology, composite index.

Introduction. The main challenge in measuring social development is its multisided nature. There is a significant number of approaches to the interpretation of the essence of social development and the determination of its components thus far. Two groups of approaches to the definition of social development 
may be specified. The first group considers social development as the process and the result of social changes under the influence of targeted actions (and under the influence of the social policy as well). Thus, social development can be considered as a configuration of the social policy, which is focused on the strengthening of three dimensions of social life - the general quality of life, life circumstances of all the members of the society and the quality of social relations (Gil, 1976). According to Midgley (1995), social development is "a process of planned social change designed to promote the well-being of the population as a whole in conjunction with a dynamic process of economic development". A dynamic approach is also proposed by UNRISD (2011), describing social development through "change that leads to improvements in human well-being, social relations and social institutions, and that is equitable, sustainable and compatible with principles of democratic governance and social justice." Abdi and Guo (2008) consider social development as a combination of a wide range of measures (economic, political, educational, and technological) that affect people's lives.

On the other hand, when defining social development, another group of scientific approaches is focused on its key characteristic aspects, such as equity and equality (Pandey, 1981; United Nations, 2005), opportunities for the people (Dominelli, 1997), improvements on the welfare (Mokate and Saavedra, 2006). Given these approaches, social development should be considered as a process of changing the basic parameters of the welfare of individuals and the level of social interaction, which occurs both under the influence of regulatory measures and independently of them. Herewith, a set of such parameters must be defined.

Analysis of recent researches and publications. Social development estimation is presented both in scientific works and in methodological developments of official organizations. At the same time, there is a lack of the unified criteria showing the essence of social development and allowing it to be estimated both at a fixed moment of time and in dynamics, which results in a significant number of existing theoretical and practical approaches.

Foa (2011) analyzes social development through three consecutive areas: economic that covers poverty reduction, social services and basic needs; human that covers literacy, education and skills, health; and social one related to social life, participation in organizations, trust and non-discrimination. When considering social capital, we emphasize the specifics of social institutions and their differences from political institutions and governance institutes, which are shown, firstly, in their independence from the state, and, secondly, in the informal nature of their functioning. Such an idea is significant in terms of identifying not only the general level of social development but also the definition of its problem areas at the level of a country. A similar cumulative approach is offered by The Social Progress Imperative (2017), developed by the Social Progress Index, with three levels of estimation (Basic Human Needs, Foundation of Wellbeing, Opportunity). The calculation methodology for the mentioned index includes estimation of the general level of social progress and ranking of the countries on a cross-country basis, as well as evaluating individual indicators and their groups, which in general can be the basis for determining the stage of social development of the country.

According to Pieper (2013), social development is a process of achieving social sustainability. The author considers, in turn, social sustainability as a set of processes focused on ensuring social quality, which lies in four interrelated aspects: social security, social empowerment, social inclusion and social cohesion. Herewith, each aspect reflects a certain subsystem of the society and is characterized by its own indicators and specific risks. This approach is theoretical and involves the formation of a preliminary list of indicators that reflect the functioning of individual subsystems of the public life provision - economic relations (social security), political relations (social empowerment), cultural relations (social inclusion) and civic relations (social cohesion). The advantage of this integrated approach is that it considers the interrelationships between individual aspects of social development. However, it brings high complexity in the formation of specific indicators for estimation and selection of methods to take into account their mutual 
influence. On the other hand, Vasilyeva et al. (2018) analyze the institutional quality of social sector through aggregation of three group indicators (healthcare, social protection, and education) in terms of the needs and priorities of the transition economy.

The majority of international and national institutions conducting research in the field of social development use, in turn, the multidimensional complex of indicators for its estimation. Thus, the International Institute of Social Studies (2017) forms six separate social development indexes, and each of them is related to its particular area. Each of the mentioned indexes includes from 11 to 42 indicators, accumulated from 26 databases (International Institute of Social Studies, 2017). It should be mentioned that not all the indicators are universal, i.e. those that are calculated for all or most of countries (statistical data according to some indicators is available in less than 20 countries). At the same time, a significant number of indicators are the result of public opinion polls, which requires special requirements for the representativeness of this type of research.

The document "Society at a Glance", developed by the Secretary-General of the OECD, divides social indicators in five directions - general context indicators and four specific groups. Formation of the statistical base according to these indicators requires the use of both OECD own data and information from other official international studies (OECD, 2014). Among the official national organizations that carry out research and provide statistics in the field of social development, special attention should be paid to the approach of the Ministry of Social Development of New Zealand. It includes 12 groups of social indicators that widely characterize the social situation (Ministry of Social Development of New Zealand, 2016), as well as the Mayor's Office of Operations of the City of New York (2016), which evaluates social indicators according to eight directions. At the same time, national approaches include most specific social indicators not typical for international organizations.

At the same time, when developing an approach to measuring social development at the level of an individual country, methodological developments on the social development estimation are of scientific interest. According to Ivanovic (1974), the following criteria should be observed when developing a selection of indicators to estimate social and economic development:

- a growing number of indicators increases the amount of information on the country's development;

- selections with the same number of indicators do not provide the same amount of information on the country's development level;

- the total amount of information, provided due to the selection of indicators, is not equal to the amount of information on the country's development, presented in each indicator in the selection;

- due to the significant correlation between two indicators, the contribution of one of them will be insignificant to the growth of the volume of information on the country's development;

- indicators, containing information provided by other indicators, should be excluded from the selection.

Unsolved questions of the general problem. The analysis of the existing approaches towards assessment of a nation's social development demonstrated the absence of a uniform interpretation of aspects, making up the main directions of social development. It necessitates elaborating a system of parameters enabling, on the one hand, taking into account the fullest range of all social life aspects; and on the other hand avoiding excessively redundant data, represented by various indicators, and consequently ensuring simplicity and ease of calculations with the use of the developed methodology (meeting requirements concerning its representativeness).

The purpose of the article is to develop a universal methodology for the social development estimation at the level of an individual country, taking into account existing approaches. According to this purpose, the objectives are:

- to generalize the main directions (components) of social development;

- to select specific indicators for the estimation of the social development components; 
- to test internal consistency and adequacy of the selection of indicators;

- to aggregate indicators in the composite index of social development.

Research findings. The basis for a composite index of social development is a formed list of the most common indicators. These indicators, on the one hand, will ensure the consideration of various characteristic features of the social situation; on the other hand, they will not duplicate each other in essence and will ensure the optimal correlation between the quantity and quality of information provided by them. Table 1 presents the successfully used by international organizations while studying issues concerning evaluating social development. Despite the absence of a uniform approach to interpreting the contents of social indicator groups by at least two different institutions, it is noteworthy that there are a number of shared groups, simultaneously taken into account in several methodologies. In particular, the most common directions are Health, Safety, Wellbeing, Empowerment and Economic Security.

Table 1 - Comparing peculiarities of grouping social indicators within different approaches (own

\begin{tabular}{|c|c|c|c|c|c|}
\hline \multicolumn{6}{|c|}{ compilation) } \\
\hline $\begin{array}{c}\text { Groups of social } \\
\text { indicators }\end{array}$ & $\begin{array}{l}\text { Mayor's Office of } \\
\text { Operations of The } \\
\text { City of New York }\end{array}$ & OECD & \begin{tabular}{|c|} 
Ministry of Social \\
Development of New \\
Zealand
\end{tabular} & $\begin{array}{c}\text { International } \\
\text { Institute of Social } \\
\text { Studies }\end{array}$ & $\begin{array}{l}\text { The Social } \\
\text { Progress } \\
\text { Imperative }\end{array}$ \\
\hline Basic Needs & & & & & + \\
\hline Education & + & & + & & \\
\hline Health & + & + & + & & \\
\hline Wellbeing & + & & + & & + \\
\hline Safety & + & & + & + & \\
\hline Equity & & + & & & \\
\hline Work & & & + & & \\
\hline Social Cohesion & & + & & + & \\
\hline \begin{tabular}{|l|} 
Social \\
Connectedness \\
\end{tabular} & & & + & + & \\
\hline People & & + & + & & \\
\hline Inclusion & + & & & + & \\
\hline Empowerment & + & & + & + & \\
\hline Economic Security & + & + & + & & \\
\hline Gender Equality & & & & + & \\
\hline Opportunity & & & & & + \\
\hline Housing & + & & & & \\
\hline Infrastructure & + & & & & \\
\hline Cultural Identity & & & + & & \\
\hline $\begin{array}{|ll|}\text { Leisure } & \text { and } \\
\text { Recreation } & \\
\end{array}$ & & & + & & \\
\hline Life Satisfaction & & & + & & \\
\hline
\end{tabular}

On the other hand, we should mention that the comparison of social development evaluation directions was carried out not only on the basis of names of separate groups within different approaches but also taking into account the social indicators making up a certain group. For instance, social development indices, used by International Institute of Social Studies (2017), were included both as they are (Gender 
Equality), and also taking into consideration their comparison with more general directions, such as Empowerment (Civic Activism), Social Connectedness (Clubs and Associations), Social Cohesion (Intergroup Cohesion), Safety (Interpersonal Safety and Trust), Inclusion (Inclusion of Minorities). In our opinion, such a direction as Inclusion can be also represented by the more specific indicator group Diverse \& Inclusive Government (Mayor's Office of Operations of The City of New York, 2016). According to Social Report Ministry of Social Development of New Zealand (2016) while evaluating social development there are employed such directions as Knowledge and skills, Economic standard of living, Civil and political rights, which can be compared with such groups as Education, Economic Safety and Empowerment accordingly. In their turn General context indicators, as defined by OECD (2014), including such criteria as Fertility, Migration, and Family, which made it possible to compare them with the group People. Selfsufficiency indicators include Employment, Unemployment, and Expected years in retirement, which can be related to such direction, as Economic Security.

The conducted analysis proved it impossible to focus on defining the most important directions while grouping social development indicators, taking into account the fact, that it is characteristic of various approaches both to use equivalent social indicator groups simultaneously in the context of general methodology elaboration, and also to distribute similar or alternative indicators differently between particular directions of the analysis. Therefore, the next stage of the research was to compare a comprehensive inventory of social indicators, applied to different approaches. According to the findings of the analysis, out of the social development indicator inventories, used by the five organizations under study, there were singled out 30 indicators simultaneously represented in two or more methodologies.

It should be mentioned, that the indicators found most common pertaining to such directions as a population's demographic condition, a population's economic condition, public trust in institutions, gender equality, social relations and social engagement, security, education, health, and psychological state. The grouping of the indicators mentioned above is fundamental for developing a set of parameters to evaluate a social condition at the level of a given nation. Evaluation of a population's demographic condition may be based upon two indicators, represented within two organizations' approaches, while other approaches don't allow for taking into account equivalent or alternative indicators for evaluating social development (see Table 2).

Table 2 - The most common indicators for evaluating the population's demographic condition (own compilation)

\begin{tabular}{|l|c|c|}
\hline Social indicators & OECD & Ministry of Social Development of New Zealand \\
\hline Fertility & + & + \\
\hline Family & + & + \\
\hline
\end{tabular}

The next group of indicators pertains to evaluating a population's economic condition as a direction for social development. It should be noted, that all the organizations under study suggest a number of indicators to evaluate this constituent (Table 3).

At that, some methodologies suggest the simultaneous use of Employment and Unemployment (OECD, 2014; Ministry of Social Development of New Zealand, 2016), which is inappropriate while forming a composite indicator of social development evaluation due to excessive information redundancy. Therefore, while evaluating a separate nation one of the indicators should be applied - namely, Unemployment, as the most common one.

Table 4 demonstrates the criteria of three organizations, which simultaneously use certain indicators of public trust in institutions. However, it should be mentioned that the methodology applied by OECD (2014) doesn't allow for direct use of such an indicator, as perceived corruption, while chapter 7 Social 
Cohesion indicators include such a parameter as Confidence in institutions, closely related to perceived corruption in the society.

Table 3 - The most common indicators for evaluating the population's economic condition (own compilation)

\begin{tabular}{|c|c|c|c|c|c|}
\hline Social indicators & $\begin{array}{l}\text { Mayor's Office of } \\
\text { Operations of The } \\
\text { City of New York }\end{array}$ & OECD & $\begin{array}{c}\text { Ministry of Social } \\
\text { Development of New } \\
\text { Zealand }\end{array}$ & $\begin{array}{c}\text { International } \\
\text { Institute of } \\
\text { Social Studies }\end{array}$ & $\begin{array}{l}\text { The Social } \\
\text { Progress } \\
\text { Imperative }\end{array}$ \\
\hline Employment & & + & + & & \\
\hline Unemployment & + & + & + & & \\
\hline Income Inequality & + & + & + & & \\
\hline Poverty & + & + & + & & \\
\hline Housing Affordability & & & + & & + \\
\hline $\begin{array}{l}\text { Telephone and } \\
\text { Internet Access in the } \\
\text { Household }\end{array}$ & + & & + & + & + \\
\hline
\end{tabular}

At the same time let's pay attention to the fact that International Institute of Social Studies (2017), to determine Civic Activism Index, doesn't take into consideration the indicators related to voting, while applying more specific indicators describing a population's political activism, e.g. Respondent says they use the radio/newspaper to inform themselves about politics or Proportion of respondents who either 'have done' or 'might' sign a petition/ join a boycott/ attend a peaceful demonstration.

Table 4 - The most common indicators concerning public trust in institutions (own compilation)

\begin{tabular}{|l|c|c|c|}
\hline Social indicators & $\begin{array}{c}\text { Mayor's Office of Operations of } \\
\text { The City of New York }\end{array}$ & $\begin{array}{c}\text { Ministry of Social } \\
\text { Development of New } \\
\text { Zealand }\end{array}$ & $\begin{array}{c}\text { The Social } \\
\text { Progress } \\
\text { Imperative }\end{array}$ \\
\hline Voter Turnout & + & + & \\
\hline $\begin{array}{l}\text { Perceived } \\
\text { Corruption }\end{array}$ & & + & + \\
\hline
\end{tabular}

Despite the fact, that only International Institute of Social Studies (2017) singles out Gender Equality as a separate direction of social development evaluation, this constituent is partly represented in other organizations' approaches, within the context of such constituents as Civil and political rights (Ministry of Social Development of New Zealand, 2016) or Diverse \& Inclusive Government (Mayor's Office of Operations of The City of New York, 2016) through the criterion Representation of Women in Government (see Table 5).

Table 5 - The most common indicators for evaluating gender equality (own compilation)

\begin{tabular}{|c|c|c|c|}
\hline Social indicators & $\begin{array}{c}\text { Mayor's Office of } \\
\text { Operations of The } \\
\text { City of New York }\end{array}$ & $\begin{array}{c}\text { Ministry of Social } \\
\text { Development of New } \\
\text { Zealand }\end{array}$ & $\begin{array}{c}\text { International } \\
\text { Institute of Social } \\
\text { Studies }\end{array}$ \\
\hline $\begin{array}{l}\text { Representation of } \\
\text { Women in Government }\end{array}$ & + & + & + \\
\hline
\end{tabular}

In their turn, more specific indicators for evaluating Gender Equality, taken into account in the 
methodology by International Institute of Social Studies (e. g. a Ratio between female and male primary school enrollment, Percentage agreeing that a married man has a right to beat his wife and children, Ratio between adult female and adult male mortality rates), were not represented by alternative indicators within other approaches.

Table 6 shows generalized indicators to evaluate social relations and social engagement. At the same time, some organizations' methodologies use specific indicators for their definition. For instance, the Tolerance indicator may be represented by such parameters, as Tolerance perception for ethnic minorities/gays and lesbians (OECD, 2014); Tolerance for immigrants/ homosexuals, Religious tolerance (The Social Progress Imperative, 2017). On the other hand, to define Helping Others some organizations use somewhat different indicators, such as Percentage respondents saying that people generally help one another in their neighborhood (International Institute of Social Studies, 2017); or Share of people who reported that they helped a stranger or someone they did not know who needed help (OECD, 2014). We should also note different levels of defining such a criterion as Voluntary Work within the mentioned approaches. For instance, Ministry of Social Development of New Zealand (2016) uses this indicator as a separate criterion within the group Social connectedness, measuring it as Proportion of population aged 15 years and over who reported doing voluntary work in the past four weeks; International Institute of Social Studies (2017) within Clubs and Associations Index of Social Development simultaneously uses a few criteria of volunteer participation, formed according to surveys (Respondent says that they use their free time to participate in voluntary associations, Percentage of respondents who are members of voluntary associations, Respondent has conducted unpaid voluntary health work), while OECD (2014) considers Share of people who reported having given volunteered time to an organization as one of the parameters, defining the general indicator of Helping Others. As concerns Perceived Discrimination indicators, it is necessary to point out, that some organizations use one general indicator to measure it (The Social Progress Imperative, 2017; Ministry of Social Development of New Zealand, 2016), while International Institute of Social Studies (2017) uses Inclusion of Minorities Index that consists of 26 specific indicators, defining various aspects of discrimination in society (e. g. The proportion of the public who would reject members of another ethnic or caste group as neighbors, Proportion of the public who think "immigration is bad for the economy", Educational Disparity Ethnic Groups).

Table 6 - The most common indicators to evaluate social relations and social engagement (own compilation)

\begin{tabular}{|c|c|c|c|c|c|}
\hline Social indicators & $\begin{array}{c}\text { Mayor's Office of } \\
\text { Operations of The City } \\
\text { of New York }\end{array}$ & OECD & $\begin{array}{l}\text { Ministry of Social } \\
\text { Development of New } \\
\text { Zealand }\end{array}$ & $\begin{array}{c}\text { International } \\
\text { Institute of } \\
\text { Social Studies }\end{array}$ & $\begin{array}{l}\text { The Social } \\
\text { Progress } \\
\text { Imperative }\end{array}$ \\
\hline Tolerance & & + & & & + \\
\hline Helping Others & & + & & + & \\
\hline $\begin{array}{l}\text { Perceived } \\
\text { Discrimination }\end{array}$ & & & + & + & + \\
\hline $\begin{array}{l}\text { Participation in Arts } \\
\text { and } \quad \text { Cultural } \\
\text { Activities }\end{array}$ & + & & + & + & \\
\hline Voluntary Work & & + & + & + & \\
\hline $\begin{array}{l}\text { Acceptance of } \\
\text { Diversity }\end{array}$ & & & + & + & \\
\hline
\end{tabular}

To evaluate the safety, four indicators (see Table 7) are most frequently used. At that, they may be subdivided into two groups - indicators that describe periodicity of criminal or dangerous situations 
(Criminal Victimisation, Road Casualties) and perception of safety by population (Safety, Fear of Crime). At the same time, lists of specific indicators, used by different organizations, are characterized by certain differences. For instance, for measuring Safety the following specific indicators are used: Community safety net (The Social Progress Imperative, 2017), Feeling of safety walking alone at night in the city or area where you live (OECD, 2014), Percentage respondents feel 'very safe' or 'fairly safe' walking alone in their area after dark, Percentage respondents feel 'very safe' or 'fairly safe' while at home after dark (International Institute of Social Studies, 2017). In their turn, Ministry of Social Development of New Zealand (2016) and International Institute of Social Studies (2017) apply similar indicators for measuring Fear of Crime, which proves the expediency of using only one of the parameters to evaluate perceived safety while constructing the social development composite index. To evaluate the level of Criminal Victimisation, official statistics are used, e. g. Proportion of population aged 15 years and over who had a crime committed against them in the last 12 months (Ministry of Social Development of New Zealand, 2016), Total persons brought into formal contact with the police and/or criminal justice system (OECD, 2014), Violent Crimes Rate per 1,000 (Mayor's Office of Operations of The City of New York, 2016) or results of surveys, e. g. Percentage of respondents who have been the victim of a street crime/burglary (International Institute of Social Studies, 2017).

Table 7-The most common indicators to evaluate safety (own compilation)

\begin{tabular}{|l|c|c|c|c|c|}
\hline \multicolumn{1}{|c|}{ Social indicators } & $\begin{array}{c}\text { Mayor's Office of } \\
\text { Operations of The } \\
\text { City of New York }\end{array}$ & OECD & $\begin{array}{c}\text { Ministry of Social } \\
\text { Development of } \\
\text { New Zealand }\end{array}$ & $\begin{array}{c}\text { International } \\
\text { Institute of } \\
\text { Social Studies }\end{array}$ & $\begin{array}{c}\text { The Social } \\
\text { Progress } \\
\text { Imperative }\end{array}$ \\
\hline Safety & + & + & + & + & + \\
\hline Criminal Victimisation & + & + & + & + & + \\
\hline Fear of Crime & + & & + & + & + \\
\hline Road Casualties & + & + & + \\
\hline
\end{tabular}

The indicators for evaluation of education while measuring social development are used only by some organizations, as seen in Table 8. At the same time we can point out, that parameters of education in the methodology by International Institute of Social Studies (2017) are taken into account as separate characteristics to construct Gender Equality or Inclusion of Minorities indices, whereas OECD (2014) uses Education spending within the context of Self-sufficiency indicators, which testifies to the expediency of using the Education indicators for social development evaluation.

Table 8 - The most common indicators to evaluate education (own compilation)

\begin{tabular}{|l|c|c|c|}
\hline \multicolumn{1}{|c|}{ Social indicators } & $\begin{array}{c}\text { Mayor's Office of } \\
\text { Operations of The City of } \\
\text { New York }\end{array}$ & $\begin{array}{c}\text { Ministry of Social } \\
\text { Development of New } \\
\text { Zealand }\end{array}$ & $\begin{array}{c}\text { The Social } \\
\text { Progress } \\
\text { Imperative }\end{array}$ \\
\hline $\begin{array}{l}\text { Early Childhood } \\
\text { Education }\end{array}$ & + & + & + \\
\hline Adult Literacy & & + & + \\
\hline
\end{tabular}

Table 9 shows the main criteria that are used for evaluating a population's health, the psychological state included. It is necessary to mention, that the most commonly used indicators are Life Expectancy and Suicide. It is noteworthy, that some methodologies also use their own subjective evaluation criteria, such as Proportion of adult population who rated their health as good (OECD, 2014; Ministry of Social Development of New Zealand, 2016) or Proportion of adult population who experienced psychological distress (Ministry of Social Development of New Zealand, 2016), also taking into account population who 
Received Mental Health Treatment (Mayor's Office of Operations of The City of New York, 2016).

Health Expenditure is considered by different organizations either through total average expenditure on health care (OECD, 2014) or through Health insurance (Mayor's Office of Operations of The City of New York, 2016)

Table 9 - The most common indicators to evaluate health and psychological state (own compilation)

\begin{tabular}{|l|c|c|c|c|c|}
\hline \multicolumn{1}{|c|}{ Social indicators } & $\begin{array}{c}\text { Mayor's Office of } \\
\text { Operations of } \\
\text { The City of New } \\
\text { York }\end{array}$ & OECD & $\begin{array}{c}\text { Ministry of Social } \\
\text { Development of } \\
\text { New Zealand }\end{array}$ & $\begin{array}{c}\text { International } \\
\text { Institute of } \\
\text { Social Studies }\end{array}$ & $\begin{array}{c}\text { The Social } \\
\text { Progress } \\
\text { Imperative }\end{array}$ \\
\hline Premature Mortality Rate & + & & & & + \\
\hline Infant Mortality Rate & + & & & & + \\
\hline Life Expectancy & & + & + & & + \\
\hline Perceived Health Status & & + & + & & + \\
\hline Suicide & & + & + & & \\
\hline Health Expenditure & + & + & & & \\
\hline Psychological Distress & + & & + & & \\
\hline
\end{tabular}

The grouping and set of indicators mentioned above may be considered fundamental for forming a set of indicators to evaluate the social condition of a nation. At the same time, as the conducted study proves, some methodologies use alternative specific indicators to evaluate equivalent general parameters. Moreover, while conducting an empirical research at the national level one may encounter a problem of the absence of statistical information by certain indicators in national and international databases, or presence of only fragmentary data across several periods. Therefore, the above-mentioned inventory of social development indicators should be considered approximate, and the possibility of substantiated exchange of some specific indicators should be kept in mind.

An important stage of conducting research to construct integral indicators is analyzing the capability of the selected criteria to describe the phenomenon under study (multivariate analysis). Handbook on Constructing Composite Indicators (OECD, 2008), for conducting this stage, suggests using one of the following methods: principal component analysis (or factor analysis), cluster analysis, or Cronbach coefficient alpha. At that, cluster analysis is used for evaluation within the context of a national sample, which is not the aim of this research.

Such methods, as principal component analysis and factor analysis are mostly used to group indicators within the context of subindices (factors or constituents), at that they are characterized by limitations concerning number of observations and variables, included in the analysis - which limitations are difficult to adhere to while making evaluations within the framework of a particular nation, considering a great number of input indicators.

In that case, it is expedient to calculate Cronbach coefficient alpha, which is used for evaluating the inner coherence of elements within a model and enables determining the quality of measuring a phenomenon under study through the totality of indicators used for evaluation.

Calculation of Cronbach coefficient alpha by means of program complex Stata 12 SE presupposes the use of standardized or unstandardized items. At that use of data, standardization is expedient if a social condition is evaluated by separate indicators, whereas the purpose of the mentioned research presupposes construction of an integral indicator, which necessitates concordance of not only statistical values of particular indicators but also directions of their dynamics within the context of social implication 
descriptions. Therefore it is expedient to calculate Cronbach coefficient alpha on the basis of normalized data.

Taking into consideration the specificity of sampling indicators for normalization, it is expedient to use the Min-Max method for two groups of indicators according to the direction, in which they characterize the phenomenon under study. The first group of indicators is characterized by direct dependence in relation to the composite index (above the value of the indicator leads to the improvement of the social development composite index). Their normalization should be carried out as follows:

$$
\widetilde{x_{t t}}=\frac{x_{i t}-x_{\min }}{x_{\max }-x_{\min }}
$$

where $\widetilde{x_{l t}}$ - the normalized value of ith indicator in the year $t$;

$x_{i t}$ - the current value of $i^{\text {it }}$ indicator in the year $t$;

$x_{\max }$ and $x_{\min }$ - the maximum and the minimum values of $i t$ across a period of research.

The other group of indicators is characterized by inverted dependence in relation to the composite index (above the value of the indicator causes worsening/dropping of the composite index). For their normalization it is expedient to apply the following formula:

$$
\widetilde{x_{i t}}=\frac{x_{i t}-x_{\min }}{x_{\max }-x_{\min }}
$$

Therefore, each indicator assumes a value within the range [0;1], where 0 is the lowest value during the research period from the standpoint of social development evaluation, 1 is the highest value. The classification of indicators into groups is presented in Table 10.

Table 10 - Classification of social indicators into groups for normalizing statistical data

\begin{tabular}{|c|c|c|c|}
\hline \multicolumn{2}{|c|}{$\begin{array}{l}\text { Indicators with direct dependence in relation to the } \\
\text { composite index }\end{array}$} & \multicolumn{2}{|c|}{$\begin{array}{l}\text { Indicators with inverted dependence in relation to the } \\
\text { composite index }\end{array}$} \\
\hline General indicators & Probable specific indicators & $\begin{array}{c}\text { General } \\
\text { indicators }\end{array}$ & Probable specific indicators \\
\hline 1 & 2 & 3 & 4 \\
\hline Fertility & Fertility rate (births per woman) & Unemployment & Unemployment (\% of total labor force) \\
\hline Family & Marriage to divorce ratio (per 1,000 ) & Income Inequality & GINI index \\
\hline $\begin{array}{l}\text { Telephone and Internet } \\
\text { Access in the Household }\end{array}$ & $\begin{array}{l}\text { Individuals using the Internet (\% of } \\
\text { the population) }\end{array}$ & Poverty & $\begin{array}{l}\text { Poverty headcount ratio at national } \\
\text { poverty lines ( } \% \text { of the population) }\end{array}$ \\
\hline Voter Turnout & $\begin{array}{l}\text { The proportion of the population } \\
\text { who votes in elections (\%) }\end{array}$ & $\begin{array}{l}\text { Housing } \\
\text { Affordability }\end{array}$ & $\begin{array}{l}\text { Housing cost of individuals ( } \% \text { of } \\
\text { household income) }\end{array}$ \\
\hline Perceived Corruption & Corruption perception index (score) & $\begin{array}{l}\text { Perceived } \\
\text { Discrimination }\end{array}$ & $\begin{array}{l}\text { People who reported they had been } \\
\text { discriminated against in the last } 12 \\
\text { months ( } \% \text { of the population) }\end{array}$ \\
\hline $\begin{array}{l}\text { Representation of } \\
\text { Women in Government }\end{array}$ & $\begin{array}{l}\text { The proportion of seats held by } \\
\text { women in national parliaments }(\%)\end{array}$ & $\begin{array}{l}\text { Criminal } \\
\text { Victimisation }\end{array}$ & $\begin{array}{l}\text { People brought into formal contact with } \\
\text { the police and/or criminal justice system } \\
\text { (per } 1,000 \text { ) }\end{array}$ \\
\hline Tolerance & $\begin{array}{l}\text { People who think that the city or } \\
\text { area where they live is a good place } \\
\text { to live for immigrants }(\%)\end{array}$ & Fear of Crime & $\begin{array}{l}\text { People who feel unsafely walking alone } \\
\text { at night in the city or area of living ( } \% \text { of } \\
\text { the population) }\end{array}$ \\
\hline
\end{tabular}
(own compilation) 
Tabl. 10

\begin{tabular}{|l|l|l|l|}
\hline \multicolumn{1}{|c|}{1} & \multicolumn{1}{|c|}{2} & \multicolumn{1}{c|}{3} & \multicolumn{1}{c|}{4} \\
\hline Helping Others & $\begin{array}{l}\text { Participation in helping a stranger } \\
\text { (\% of the population) }\end{array}$ & Road Casualties & $\begin{array}{l}\text { Motor vehicle traffic fatalities (per } \\
1,000)\end{array}$ \\
\hline $\begin{array}{l}\text { Participation in Arts and } \\
\text { Cultural Activities }\end{array}$ & $\begin{array}{l}\text { People who actively participated in } \\
\text { the arts } \% \text { of the population) }\end{array}$ & $\begin{array}{l}\text { Early Childhood } \\
\text { Education }\end{array}$ & $\begin{array}{l}\text { Children out of school (\% of primary } \\
\text { school age) }\end{array}$ \\
\hline Voluntary Work & $\begin{array}{l}\text { Participation in volunteering time } \\
\text { (\% of the population) }\end{array}$ & $\begin{array}{l}\text { Premature Mortality } \\
\text { Rate }\end{array}$ & $\begin{array}{l}\text { Death before the age of } 65 \text { (per } \\
1,000)\end{array}$ \\
\hline Acceptance of Diversity & $\begin{array}{l}\text { People who feel comfortable } \\
\text { towards a neighbor from the } \\
\text { minority group (\% of the } \\
\text { population) }\end{array}$ & Infant Mortality Rate & $\begin{array}{l}\text { Mortality rate, under-5 (per 1,000 live } \\
\text { births) }\end{array}$ \\
\hline Life Expectancy & $\begin{array}{l}\text { Literacy rate, adult (\% of people } \\
\text { ages 15 and above) }\end{array}$ & Suicide & Suicide mortality rate (per 100,000) \\
\hline Perceived Health Status & $\begin{array}{l}\text { Life expectancy at birth (years) } \\
\text { health }(\% \text { of the population) }\end{array}$ & $\begin{array}{l}\text { Psychological } \\
\text { Distress }\end{array}$ & $\begin{array}{l}\text { Psychological distress rate }(\% \text { of } \\
\text { people ages 15 and above) }\end{array}$ \\
\hline Health Expenditure & $\begin{array}{l}\text { Health expenditure, public (\% of } \\
\text { total health expenditure) }\end{array}$ & & \\
\hline
\end{tabular}

The next stage of forming an integral indicator is choosing a way of aggregating separate social indicators. Taking into account the different periodicity of using particular social indicators, for aggregating indicators, it is expedient to calculate weight coefficient with the help of Simple Additive Weighting method (Afshari, Mojamed and Yusuff, 2010). The criteria, determining the measure of significance, is defined as a frequency of a particular social condition indicator presence in national and international methodologies.

The composite index of social development for a particular nation is calculated using the following formula:

$$
I S S_{t}=\sum_{i=1}^{n} w_{t} \widetilde{x_{l t}}
$$

where $w_{t}$ is the weight of ith indicator.

Consequently, the social development index may assume a value [0;1]. The approbation of the proposed index of social development was carried out on the example of Ukraine. The peculiar features of the realization of separate stages of estimation are demonstrated on figure 1. It should be mentioned that there is no statistical information presented according to individual indicators in domestic and foreign databases, or it is available only for several periods. Therefore, the selection was narrowed to 19 indicators, and also a part of specific indicators was replaced by indicators similar in their nature.

Thus, for the characteristics of the demographic situation of the population we included a fertility index, which reflects the average number of births per woman in the country (World Bank Group, 2018), as well as a relative increase in the number of marriages per thousand, which takes into account the number of marriages and divorces (State Statistics Service of Ukraine, 2018). The parameters of the economic situation of the population in the selection for Ukraine were the level of general unemployment, the poverty rate, the Gini index as an indicator of the unequal distribution of the people's income, as well as the percentage of Internet users (World Bank Group, 2018). At the same time, national and international statistical databases do not provide relevant statistics to characterize the affordability of housing in Ukraine. Indicators of confidence in institutions and gender equality were formed on the basis of indicators presented in international statistical databases (World Bank Group, 2018; Transparency International Ukraine, 2018). 

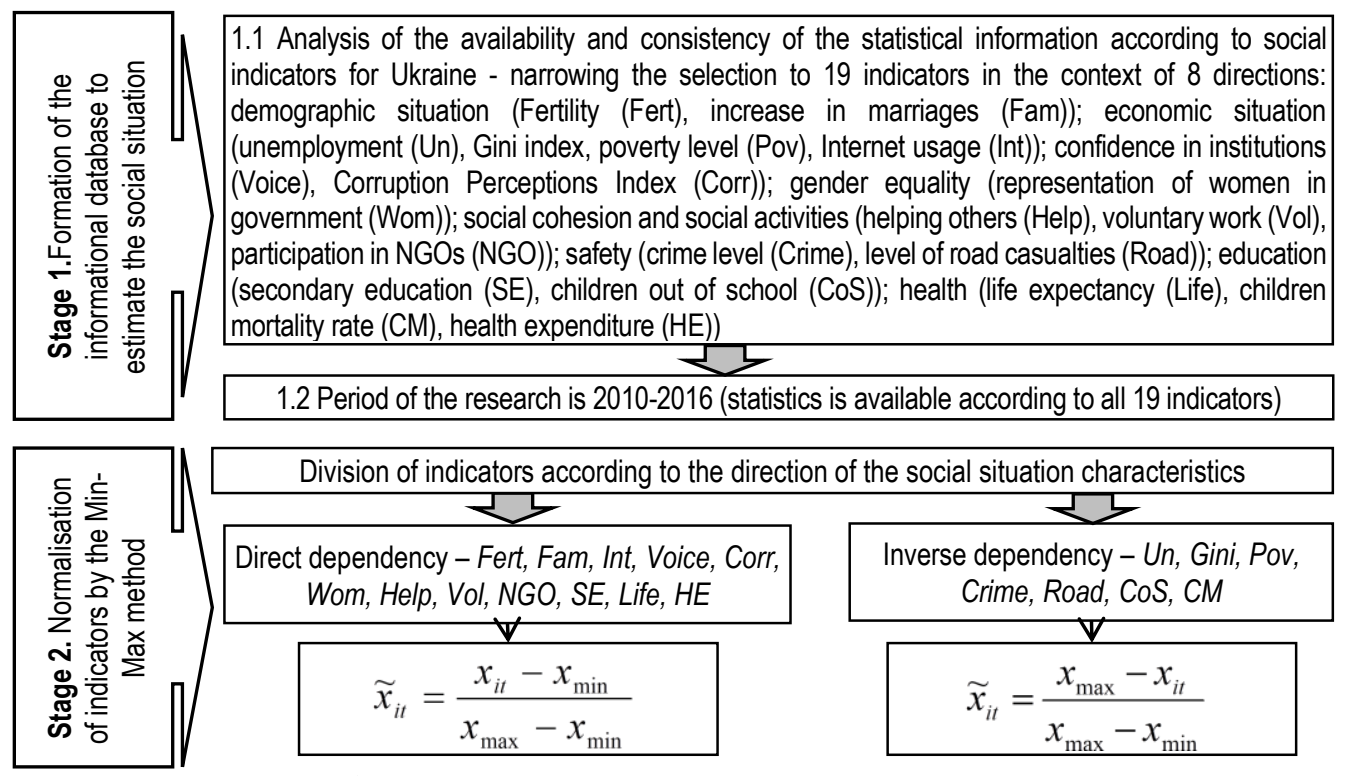

Stage 3. Check the
internal consistency of the
statistical selection

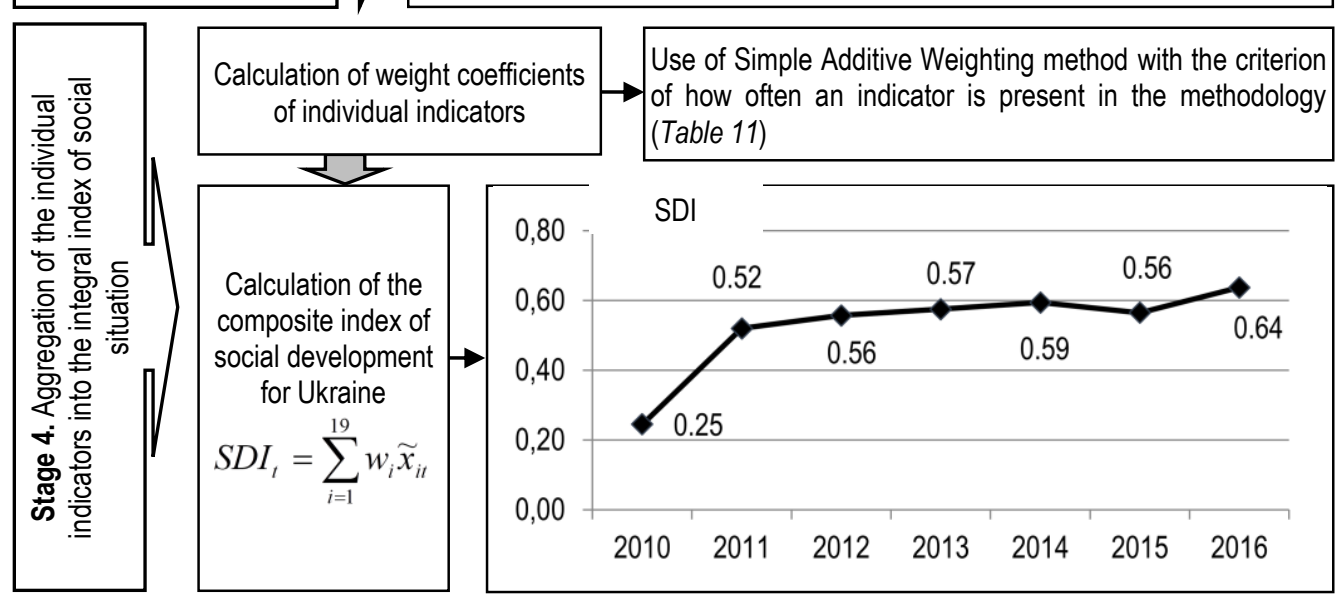

Figure 1 - Estimation of social development: the case for Ukraine (own data)

The group of indicators of social cohesion and social activity included the indicators of voluntary work and helping others (Charities Aid Foundation, 2018), which characterize social connections, the parameter of participation in public organizations as an indicator of social activity (State Statistics Service of Ukraine, 2018). At the same time, Ukraine has only fragmentary statistics that characterize tolerance and acceptance of diversity, which did not allow them to be included in the statistical selection of indicators. 
Table 11 - Weighting of social indicators (own calculations)

\begin{tabular}{|c|c|c|c|c|c|c|c|c|c|c|c|c|c|c|c|c|c|c|c|c|}
\hline SI & 䓌 & 芯 & $\underline{E}$ & . & ذั้ & हે & $\frac{\text { 웜 }}{1}$ & $\overline{8}$ & $\begin{array}{l}\text { O্ } \\
Z\end{array}$ & 惢 & 选 & 뽀 & ร & $\sum_{0}$ & లె & $\begin{array}{l}\text { वृ } \\
\text { व్ }\end{array}$ & : & ฉ্ & :름 & Weiaht \\
\hline it & & 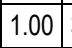 & & 1.00 & 1.002 & 2.00 & 1.00 & 2.00 & 2.00 & 02 & 2.00 & 1.00 & 2.00 & 00 & 2.00 & 3.00 & 4.00 & 2.00 & 00 & .029 \\
\hline Fam & 1 & 00 & ] & 00 & 02 & 00 & 1.00 & 0 & 2.00 & .002 & 0 & 0 & 0 & 02 & 2.00 & 3.00 & 4.00 & 00 & 200 & 29 \\
\hline Int & 3 (C) & 33 & (1) & 0.33 & 330 & .67 & 0.33 & 7 & 0.67 & $\begin{array}{ll}3 & 0\end{array}$ & $7 \mid c$ & 3 & 0.67 & 33 & 0.67 & 1.00 & 1.33 & 67 & 0.67 & 088 \\
\hline oice & 0 & 0 & (1) & 1.00 & 022 & 00 & 1.00 & 0 & \begin{tabular}{|l|}
2.00 \\
\end{tabular} & 02 & 0 & 0 & 2.00 & 02 & 2.00 & 3.00 & 4.00 & 00 & 00 & 029 \\
\hline Corr & 0 & .00 & .00 & 1.00 & 1.002 & 2.00 & 1.00 & 0 & 2.00 & 2 & 0 & 0 & 2.00 & 00 & 2.00 & 3.00 & 4.00 & 00 & 200 & 0.029 \\
\hline Won & $0 \mid 0$ & 0.50 & 1.50 & 0.50 & 0.50 & 0 & 0.50 & 0 & 1.00 & 0.50 & 0 & 0 & 0 & 0.50 & 1.00 & 02 & 0 & 0 & 100 & 2059 \\
\hline Help & 00 & 1.00 & 3.00 & 1.00 & 1. & 0 & 1.00 & 0 & 2 & 1.002 & b. & 0 & 0 & 1.00 & 2.00 & 2 & 4.00 & 0 & 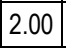 & 0.029 \\
\hline Vol & $0 \mid \mathrm{C}$ & ( & 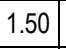 & 0 & 0. & 0 & 0.50 & 0 & 1.00 & 0 & 0 & 0 & 0 & 0 & 1.00 & 2 & 2.00 & 0 & 100 & 0.059 \\
\hline NGO & 0 & $\left(C^{2}\right.$ & 1.50 & 0.50 & 0.50 & 0 & 0 & 0 & 1 & 0 & 0 & 0 & 0 & 0 & 0 & 2 & 0 & 0 & 100 & 0.059 \\
\hline SE & 1.00 & 00 & .00 & 1.00 & 1.002 & 2.00 & 1.00 & 2.00 & 2.00 & $\begin{array}{ll}02 \\
\end{array}$ & 2.00 & 1.00 & 2.00 & 1.00 & 2.00 & 3.00 & 4.00 & 2.00 & 2.00 & 2 \\
\hline Life & 50 & 0.50 & 50 & 0.50 & 0.50 & .00 & 0.50 & 1.00 & 1.00 & 0.50 & 1.00 & 0.50 & 1.00 & 0.50 & 1.00 & 1.50 & 2.00 & 1.00 & 1.0 & 05 \\
\hline $\mathrm{HE}$ & 1.00 & 00 & 00 & 1.00 & 1.002 & .00 & 1.00 & 2.00 & 2.00 & 1.002 & 2.00 & 1.00 & 2.00 & 1.00 & 2.00 & 3.00 & 4.00 & 2.00 & 2.00 & 0.02 \\
\hline Un & .50 & 50 & 50 & 0.50 & 0.50 & .00 & 0.50 & 1.00 & \begin{tabular}{|l|}
1.00 \\
\end{tabular} & 0.50 & 1.00 & \begin{tabular}{|l|}
0.50 \\
\end{tabular} & 1.00 & 0.50 & 1.00 & 1.502 & 2.00 & 1.00 & 1.0 & .05 \\
\hline $\mathrm{CM}$ & .00 & 0 & 3.00 & 1.00 & 1.002 & 2.00 & .00 & 0 & 2.00 & 02 & 2.00 & 1.00 & 2.00 & 1.00 & 2.00 & 3.00 & 4.00 & .00 & 2.00 & .02 \\
\hline $\operatorname{Cos}$ & 50 & 50 & 50 & 0.50 & 0.50 & 00 & 0.50 & 0 & 1.00 & 50 & 0 & 0.50 & 1.00 & .50 & 1.00 & 1.50 & 2.00 & 00 & 1.00 & .05 \\
\hline Road & \begin{tabular}{l|l}
0.33 \\
\end{tabular} & 0.33 & 00 & 0.33 & 30 & 77 & 33 & $0.67 \mid$ & 0.67 & 30 & 76 & 0 & 7 & 33 & 0.67 & 1.00 & 1.33 & 0.67 & 0.67 & 08 \\
\hline $\mathrm{me}$ & 20 & 1 & 050 & 25 & 250 & 50 & 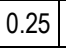 & 0.50 & .50 & 50 & 0.50 & 0 & 0 & 5 & 0.50 & 0.50 & 1.00 & 50 & 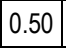 & 0118 \\
\hline 10v & 0.50 & 0 & 1.00 & 50 & 0.50 & 0 & 0.00 & 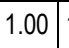 & 0 & 0. & c & & 0 & 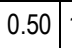 & 0 & 1 & 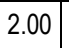 & 01 & 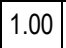 & 0,59 \\
\hline G & 0 & t & & 0.50 & 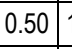 & & 0.50 & 1.00 & 0 & & & & 0 & 0 & 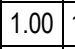 & 025 & 0 & 0 & 1.00 & 0.059 \\
\hline rali & 12.9 & 4 & 5 & 2.9 & 12.92 & 8 & .9 & 25.8 & 5.8 & 12.9 & 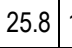 & 1 & 8 & 12.9 & 25.8 & .5 & 6 & 8 & 25.8 & 1.000 \\
\hline
\end{tabular}

The group of safety was formed on the basis of two general indicators of the level of crime (State Statistics Service of Ukraine, 2018) and the level of road casualties in Ukraine (Management of Road Safety of Ukraine, 2018), taking into account the lack of statistical data on the level of safety and fear of crime according to own estimates of the population. Indicators of education were determined at the level of children and adults through the ratio of children out of primary school, as well as the level of secondary education that characterizes adult literacy (World Bank Group, 2018). The last group of social indicators health and psychological status was formed on the basis of international statistical indicators on the life expectancy, children mortality and health expenditure (World Bank Group, 2018). At the same time, for parameters that show the psychological status of the population, only fragmentary data are available for separate periods, which did not allow them to be included in the selection.

Calculation of the Cronbach coefficient alpha was performed on the basis of the normalized data (12 indicators with direct dependency with the integral index, 7 indicators with inverse dependency) by the means of the software complex Stata 12 SE, which showed the proper level of internal consistency of items (e.g, Cronbach coefficient alpha for unstandardized data without their normalization was 0.1559 ).

The use of the Simple Additive Weighting method to determine the weight coefficients of integral indicators considers the frequency of use of individual indicators in international methodologies for social development estimation. The ratio of the individual indicators weight is shown in Table 11.

The value of the composite index of social development calculated in the dynamics demonstrates a tendency towards the gradual improvement of social development of Ukraine. Herewith, the maximum value of the indicator was reached in 2016 . At the same time, during the period under study, there was a 
decline in the index by the results of 2015 as compared to the previous period.

As to the improvement of the social policy in the country, the changes in the structure of the index during the analyzed period should be considered separately (see figure 2).

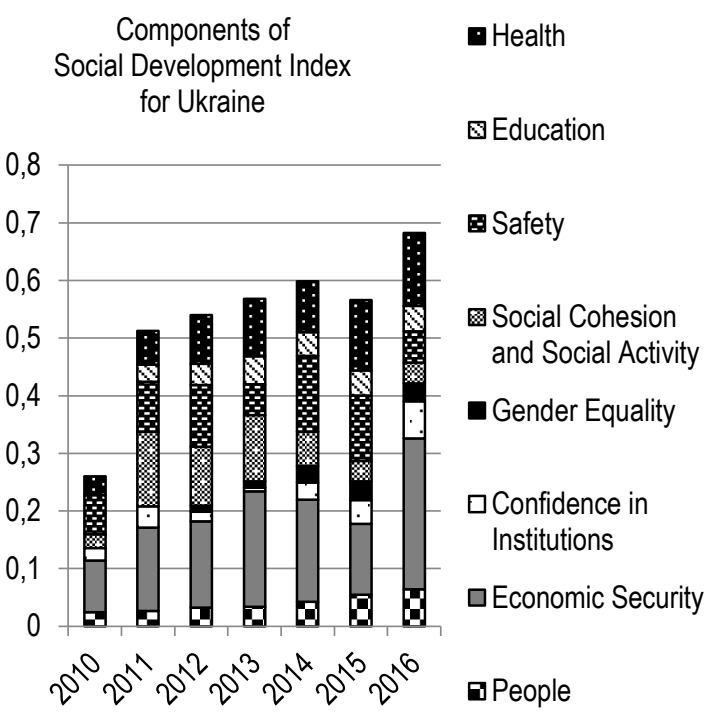

Average values of components of Social Development Index

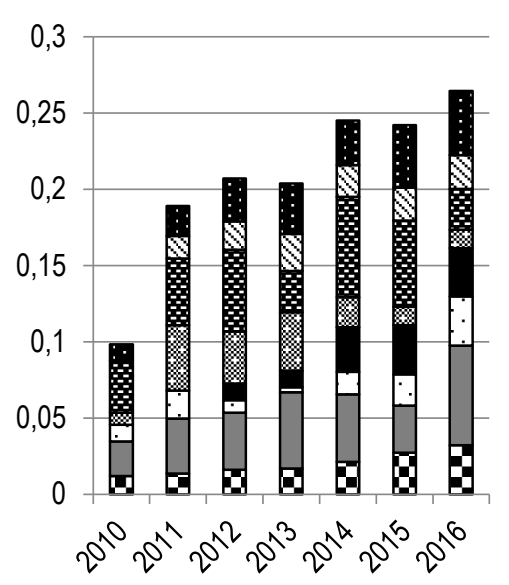

Figure 2 - Dynamics of the main directions of social development of Ukraine for the period of 2010-2016 in terms of components of the composite Social Development Index (own calculations)

The graph shows the absence of monotonous trends in most groups of the indicators under study. Thus, the tendency to constant growth is demonstrated only by indicators characterizing the demographic situation of the population. At the same time, the economic situation of the population reaches its maximum value in 2016, with a gradual improvement for 2010-2013 and a deterioration in 2014-2015. The overall analyzed period also demonstrates improvements in indicators of health, confidence in institutions and gender equality. At the same time, the parameters of safety, social cohesion and social activity show a deterioration of the overall level in the recent years compared with previous periods. Indicators of education possess the smallest variation during the period of research.

Given the different quantity of social indicators in individual components of the index, the graph also shows the average values of components of the Social Development Index, calculated as component values, divided by the number of social indicators that the component contains. It should be mentioned that in general, the average level of individual components is characterized by almost the same dynamics with their generalized values. The most significant smoothing of values is for the Economic Security and Gender Equality component, which is quite natural, since the Economic Security Group has the largest number of indicators, while Gender Equality is the smallest.

Conclusions. Theoretical part of this paper has allowed generalizing the approaches to treat the essence of the social development and to define that its main characteristics are: 1) dynamism (process of change of social indicators); 2) multidimensionality (significant quantity of parameters that reveal this category); 3) interaction (within society as well as between society and state). Analysis of international and national methods of social development estimation has proved the existence of substantial differences in the determination of main resumptive directions (groups of indicators), which should be utilized to assess 
social development. In its turn, a comparative analysis of the use of particular indicators has shown that out of 306 segregate indicators used by five different methods, 28 indicators are in operation of at least two out of five organizations that carry out research in the field of social development.

The choice of 28 social indicators became fundamental for working-out a multipurpose method of social development estimation for a selected country. The research is based on 4 main phases: 1) analysis of availability and systemic nature of a statistic information on social indicators at the country level correction of the set of indicators (if required); 2) normalization of data using minimaxing method; 3 ) examination of the internal data alignment - calculating Cronbach coefficient alpha; 4) calculation of weight ratio using Simple Additive Weighting method with aggregation of data into a composite index of social development. Data approbation on an example of Ukraine has proved a progressive improvement of social development during 2010-2016, which got reached by means of such components as People, Health, Confidence in Institutions and Gender Equality. Along with this, indicators of Safety, Social Cohesion and Social Activity in general for the period have declined, while Economic Security has been characterized by an unstable level.

Prospects for further research. The results of calculations obtained for Ukraine may be used for a complex characteristics of its social development as a result variable, on which an influence of instruments of the state regulation of economics is being directed (both for estimation of effectiveness of conducted regulative actions and from the point of view of development of effective mechanisms directed at reaching the well-balanced social, economic and political development of the country). The results of changes in the index structure create a basis for correction of the main areas of social policy in Ukraine. The created method for estimation of social development may be used for a further research in conducting crosscountry analysis.

Acknowledgment. The survey was supported by the Ministry of Education and Science of Ukraine and performed the results of the project "Modeling and forecasting of the socio-economic-political road map of reforms in Ukraine for the transition to a sustainable growth model" (registration number 0118U003569)

Abdi, A. A. \& Guo, S. (2008). Education and Social Development. Global Issues and Analyses. Rotterdam: Sense Publishers. Afshari, A., Mojamed, M. \& Yusuff R. M. (2010). Simple Additive Weighting Approach to Personnel Selection Problem. International Journal of Innovation, Management and Technology, 1 (5), 511-515.

Charities Aid Foundation (2018). World Giving Index. Retrieved fromhttps://www.cafonline.org/about-us/publications.

Dominelli, L. (1997). Social Work and Social Development: A Partnership in Social Change. Journal of Social Development in Africa, 12 (1), 29-38.

Gil, D. G. (1976). Social Policies and Social Development - A Humanistic-Egalitarian Perspective. The Journal of Sociology \& Social Welfare, 3(3), 242-263.

Foa, R. (2011). Indices of Social Development Handbook. Retrieved from http://www.indsocdev.org/resources/Indices\%20of\%20Social\%20Development\%20Handbook.pdf.

International Institute of Social Studies (2017). Indices of Social Development. Retrieved from http://www.indsocdev.org/home.html.

Ivanovic, B. (1974). A Method of Establishing a List of Development Indicators. Social indicators: problems of definition and selection. Unesco reports and papers in the social sciences, 30, 21-26.

Lyulyov, O., Chortok, Y., Pimonenko, T., \& Borovik, O. (2015). Ecological and economic evaluation of transport system functioning according to the territory sustainable development. International Journal of Ecology and Development, 30(3), 1-10.

Management of Road Safety of Ukraine (2018). Statistics of casualties in Ukraine. Retrieved from http://www.sai.gov.ua/ua/ua/static/21.htm.

Mayor's Office of Operations of The City of New York (2016). Social Indicators Report. Retrieved from http://www1.nyc.gov/site/opportunity/reports/social-indicators-report.page.

Midgley, J. (1995). Social Development: The Developmental Perspective in Social Welfare. Thousand Oaks, CA: Sage Publications.

Ministry of Social Development of New Zealand (2016). The Social Report 2016. Retrieved from http://socialreport.msd.govt.nz/. Mokate, K. \& Saavedra J. J. (2006). Management for Social Development: An Integrated Approach to the Management of Social Policies and Programs. INDES Working paper series, I-62, 34. 


\section{K. Kyrychenko, Y. Samusevych, L. Liulova, K. Bagmet. Innovations in Country's Social Development Level Estimation}

Pandey, R. S. (1981). Strategies for social development: An analytical approach. In J. F. Jones, \& R. S. Pandey (Eds.), Social development: Conceptual, methodological and policy issues. Delhi: Macmillan India.

Pieper, R. (2013, November). Social Sustainability and Social Development: An Integrated Approach. Paper presented at the Global Social Policy Forum, THL, Finland.

OECD (2008). Handbook on Constructing Composite Indicators. Methodology and user guide. Retrieved from https://www.oecd.org/sdd/42495745.pdf.

OECD (2014). Society at a Glance 2014: OECD Social Indicators. Retrieved from http://dx.doi.org/10.1787/soc_glance-2014en.

State Statistics Service of Ukraine (2018). Demographic and social statistics. Retrieved from https://ukrstat.org/uk/operativ/oper_new.html.

The Social Progress Imperative (2017). Social Progress Index 2017. Retrieved from https://www.socialprogressindex.com/assets/downloads/resources/en/English-2017-Social-Progress-Index-Findings-

Report_embargo-d-until-June-21-2017.pdf.

Transparency International Ukraine (2018). Corruption Perception Index. Retrieved from https://ti-ukraine.org/cpi/.

United Nations (2005). The Social Summit Ten Years Later. New York: United Nations.

UNRISD (2011). Social Development in an Uncertain World. Retrieved from http://www.unrisd.org/research-agenda.

Vasilyeva, T., Lyeonov, S., Adamičková, I. and Bagmet, K. (2018) Institutional quality of social sector: The essence and measurements. Economics and Sociology, 11(2),248-262.

World Bank Group (2018). World Bank Open Data. Retrieved from https://data.worldbank.org/.

К. І. Кириченко, начальник відділу міжнародних зв'язків, Сумський державний університет (Суми, Україна);

Я. В. Самусевич, к.е.н., старший викладач, Сумський державний університет (Суми, Україна);

Л. Ю. Люльова, аспірант, Сумський державний університет (Суми, Україна);

K. В. Багмет, к.е.н., докторант, Сумський державний університет (Суми, Україна).

Інновації в оцінюванні рівня соціального розвитку країни

В науковій літературі описана значна кількість підходів та параметрів, які в тій чи іншій мірі характеризують соціальний розвиток країни, що обумовлює необхідність вибору найбільш загальних індикаторів та розробки комплексного методичного інструментарію. У статті досліджено сутність та визначено основні характерні риси соціального розвитку - справедливість та рівність, можливості для людей, добробут, тощо. Проведено аналіз існуючих підходів до оцінювання соціального розвитку, в межах кожного з них здійснено порівняння особливостей групування соціальних показників. Авторами запропоновано інноваційну методику оцінювання соціального розвитку, яка буде універсальною для будь-яких країн, та реалізовуватиметься в межах наступних етапів: 1) порівняльний аналіз напрямків соціального розвитку, а також складу конкретних індикаторів у різних методиках їх оцінювання; 2) нормалізація індикаторів для приведення їх до співставного вигляду (метод мінімакс); 3) тестування внутрішньої узгодженості індикаторів (коефіцієнт альфа Кронбаха); 4) зважування індикаторів (простий аддитивний метод). Сформований базовий набір індикаторів оцінювання соціального розвитку країни включає 28 показників, які можна розділити на вісім груп. 3 урахуванням національних особливостей відображення статистичної інфрормації композитний індекс соціального розвитку для України було розраховано на основі 19 конкретних індикаторів. Результати оиінювання засвідчили загальне перманентне покращення соціального розвитку за період 2010-2016 рр., яке відбувалося також за більшістю компонент у структурі індексу, за винятком показників безпеки, соціальної єдності та соціальної активності, які в цілому за даний період знизилися, в той час як показники економічної безпеки - характеризувалася нестабільною діяльністю.

Ключові слова: соціальний розвиток, оцінювання, Україна, методологія, композитний індекс. 